\title{
Vitamin A regulates intramuscular adipose tissue and muscle development: promoting high-quality beef production
}

\author{
Dong Qiao Peng ${ }^{1}$ (D), Stephen B. Smith ${ }^{2}$ (D) and Hong Gu Lee ${ }^{1 *}$ (D)
}

\begin{abstract}
During growth in cattle, the development of intramuscular adipose tissue and muscle is dependent upon cell hyperplasia (increased number of adipocytes) and hypertrophy (increased size of adipocytes). Based on the results of previous studies, other adipose tissue depots (e.g., perirenal and subcutaneous) develop from the fetal stage primarily as brown adipose tissue. The hyperplastic stage of intramuscular adipose is considered to develop from late pregnancy, but there is no evidence indicating that intramuscular adipose tissue develops initially as brown adipose tissue. Hyperplastic growth of intramuscular adipose continues well into postweaning and is dependent on the timing of the transition to grain-based diets; thereafter, the late-stage development of intramuscular adipose tissue is dominated by hypertrophy. For muscle development, hyperplasia of myoblasts lasts from early (following development of somites in the embryo) to middle pregnancy, after which growth of muscle is the result of hypertrophy of myofibers. Vitamin A is a fat-soluble compound that is required for the normal immunologic function, vision, cellular proliferation, and differentiation. Here we review the roles of vitamin A in intramuscular adipose tissue and muscle development in cattle. Vitamin A regulates both hyperplasia and hypertrophy in in vitro experiments. Vitamin A supplementation at the early stage and restriction at fattening stage generate opposite effects in the beef cattle. Appropriate vitamin A supplementation and restriction strategy increase intramuscular adipose tissue development (i.e., marbling or intramuscular fat) in some in vivo trials. Besides, hyperplasia and hypertrophy of myoblasts/myotubes were affected by vitamin A treatment in in vitro trials. Additionally, some studies reported an interaction between the alcohol dehydrogenase-1C (ADH1C) genotype and vitamin A feed restriction for the development of marbling and/or intramuscular adipose tissue, which was dependent on the timing and level of vitamin A restriction. Therefore, the feed strategy of vitamin A has the visible impact on the marbling and muscle development in the cattle, which will be helpful to promote the quality of the beef.
\end{abstract}

Keywords: Adipose tissue, Cattle, Intramuscular adipose tissue, Muscle development, Vitamin A

\footnotetext{
* Correspondence: hglee66@konkuk.ac.kr

${ }^{1}$ Department of Animal Science and Technology, Sanghuh College of Life Sciences, Konkuk University, Seoul 05029, South Korea

Full list of author information is available at the end of the article
}

C C The Author(s). 2021 Open Access This article is licensed under a Creative Commons Attribution 4.0 International License, which permits use, sharing, adaptation, distribution and reproduction in any medium or format, as long as you give appropriate credit to the original author(s) and the source, provide a link to the Creative Commons licence, and indicate if changes were made. The images or other third party material in this article are included in the article's Creative Commons licence, unless indicated otherwise in a credit line to the material. If material is not included in the article's Creative Commons licence and your intended use is not permitted by statutory regulation or exceeds the permitted use, you will need to obtain permission directly from the copyright holder. To view a copy of this licence, visit http://creativecommons.org/licenses/by/4.0/. The Creative Commons Public Domain Dedication waiver (http://creativecommons.org/publicdomain/zero/1.0/) applies to the data made available in this article, unless otherwise stated in a credit line to the data. 


\section{Introduction}

In recent years, with the improvement of national economies, more consumers are willing to pay for highquality beef with satisfaction, and beef cattle producers also benefit from high-quality beef production. In beef production, beef quality and beef quantity are two of the most critical factors in the beef grading system in many countries such as the USA, South Korea, and Japan [13]. Vitamin A is a fat-soluble vitamin, which is an essential substance to maintain a healthy vision and primary physiological function of cattle $[4,5]$. Vitamin A was first found to be negatively correlated with marbling score in carcasses of Japanese Black steers [6]. This was supported by numerous studies on adipocyte development with vitamin A restriction strategy in beef cattle during fattening period [7-9], as well as research in in vitro models [10-12]. In addition, the in vitro trial in human and mouse cell model indicated that vitamin A upregulated the preadipocyte genes, but downregulated the adipogenesis level in the [13]. Also, recent study in Angus beef cattle reported that vitamin A supplementation at only birth stage enhanced the final marbling development [14]. These studies suggested that vitamin A feeding strategy might have different effect on marbling development at different stage of the beef cattle. At the same time, the relationship between vitamin A supplementation and muscle development was also investigated in in vivo and in vitro studies $[15,16]$. These studies have demonstrated that vitamin $\mathrm{A}$ has a profound impact on adipocyte and muscle development in beef cattle.

\section{Vitamin A digestion, metabolism, and physiological function}

Vitamin A is a fat-soluble compound required in the diet of many animals, including ruminants [5]. Vitamin A can be absorbed by ruminants from plant sources (as carotenoids, or provitamin A) and feed additives (as retinol or retinyl ester, or preformed vitamin A) [17]. In ruminants, after vitamin A compounds enter the small intestine, mixed micelles containing digested lipid components are transported to intestinal mucosal cells [18]. In the enterocytes (mucosal cells), carotenoids and preformed vitamin A are converted to retinol or retinyl ester under the action of multiple enzymes, including $\beta$ carotene 15,15'-monooxygenase, lecithin:retinol acyltransferase and acyl-CoA:retinol acyltransferase [19-21]. Retinyl esters are transported to various tissues, including the liver primarily by the lymph circulation system, but also in the vascular system in the form of chylomicrons [22]. In the hepatocytes, retinyl esters contained in chylomicron remnants are taken up and hydrolyzed to retinol for further physiological functions in other target cells [17]. When transported to the target cell, retinol can be reversibly oxidized into retinal by retinol dehydrogenase (RDH) and alcohol dehydrogenase (ADH) $[23,24]$. Retinal can be converted to retinoic acid by the oxidation of retinaldehyde by aldehyde dehydrogenases (RALDH or ALDH) [23, 25].

Numerous physiological functions of vitamin A are achieved through retinal and retinoic acid. Retinoic acid regulates gene expression through factors bound to the retinoic acid-responsive element, retinoic acid receptor (RAR), retinoid X receptor (RXR) [24]. All-trans and 9cis retinoic acids are the primary isoforms that regulate gene expression [26]. In addition, the cellular retinoic acid-binding proteins (CRABP1 and 2), which can bind retinoic acid efficiently and involve in transporting retinoic acid into the nucleus [27]. Previous paper reviewed that CRABP1 could balance the concentration of the retinoic acid by regulating the catabolism of retinoic acid and mediated the non-transcriptional function of retinoic acid by the CRABP1-retnoic acid complex [28]. CRABP2 might inhibit the cell proliferation by passing retinoic acid to RAR, which also involved in the regulation of the preadipocyte differentiation [28-30]. The excess retinol is stored in stellate cells of the liver after being re-esterified to retinyl esters [26]. The liver provides the primary storage site for vitamin $\mathrm{A}$, and more than $95 \%$ of vitamin A exists in the liver in the form of retinyl esters [31]; the stellate cells are responsible for approximately $80 \%$ of the total retinyl ester storage [22].

Multiple physiological functions of vitamin A have been determined. Vitamin A participates in the formation of rhodopsin (visual purple) for night vision and is required for normal epithelial cell function [18]. Vitamin $\mathrm{A}$ and carotenoids have antioxidant activity via scavenging of peroxyl radicals and singlet oxygen [32, 33]. Other studies reported that retinoids are associated with cell proliferation, differentiation, and gene expression via cytosolic retinol-binding protein and cytosolic retinoic acid-binding proteins $[34,35]$.

\section{Fetal and postnatal development of adipose tissue and muscle in bovine calves \\ Fetal and postnatal development of brown and white adipose tissue}

Brown adipose tissue (BAT) and white adipose tissue (WAT) develop in the second or early third trimester of pregnancy in cattle [36]. Perirenal adipose tissue differentiates initially as BAT, but subcutaneous adipose tissue also expresses uncoupling protein-1 (UCP1, a halmark of BAT) and contains a mixture of brown and white adipocytes [37]. WAT stores energy [33] and BAT primarily is responsible for neonatal heat production [38, 39], and both WAT and BAT are sensitive to maternal nutrition and endocrine environment [36, 40, 41]. An increase in adipose tissue mass involves both hyperplasia (increase 
in cell number, i.e., adipocyte progenitor cell proliferation) and hypertrophy (increase in cell s ize, i.e., lipogenesis and triglyceride accumulation) [42-44].

There are four primary types of adipose tissue in livestock species: visceral, subcutaneous, intermuscular, and intramuscular adipose tissue (also called marbling) [45]. Visceral adipose tissue (which in this discussion includes perirenal adipose tissue) develops first, followed by subcutaneous, intermuscular, and intramuscular adipose in growing cattle. As indicated above, subcutaneous adipose tissue (and perhaps seam adipose tissue) of newborn calves contain a mixture of brown and white adipocytes, which probably different from the initial fetus period performs as $B A T$. However, fetal muscle does not express UCP1 [37], so development of fetal muscle is unlikely the intramuscular adipose tissue which develops as $B A T$ in the initial fetus period. Progenitor cells for intramuscular adipose tissue are present in bovine muscle, but lipid synthesis and triglyceride accumulation occur postweaning, and not until the calves are transitioned to a high-energy, corn-based diet [46, 47]. Subcutaneous and intramuscular adipose tissue (and probably all adipose tissue depots) retain the capacity to proliferate in mature cattle [48], so bovine adipose tissue mass increases initially by hyperplasia and then mainly by hypertrophy.

\section{Muscle development during fetal and postnatal stage}

In mammals, skeletal muscle represents more than 50\% of body mass, and muscle mass is determine by the number and size of the muscle fibers [49]. Skeletal muscle growth is initiated early in embryonic development, at which time myoblasts derived from somites undergo extensive hyperplasia until approximately midgestation, followed by increasing myotube and size prenatally [50]. From late gestation onward, muscles increase in mass by hypertrophy as new myofibrils are added to existing muscle fibers [51, 52]. Specifically, the primary embryonic muscle fiber develops from 30 days of gestation and lasted for 3 months, and major myofibers mature into slow type I muscle fibers [53]. Secondary muscle fibers are generated at the termination of primary muscle fiber development and lasts to midgestation. These secondary muscle fibers differentiate mostly into fast type II muscle fibers and a few developed into type I fibers, whose fiber type can be converted to other fiber types according to postnatal conditions [54]. The total number of muscle fibers is fixed around the mid-gestation (around 180 days of post-conception in cattle) $[54,55]$. Tertiary muscle fiber development starts from 110 days of gestation and maintains an undifferentiated state at birth, based on the fast and slow myosin heavy chain $(\mathrm{MyHC})$ isoform expression of fibers in the bovine muscle $[49,54,55]$. It was reported that cattle had type I, IIa, and IIX types of mature $M y H C$ isoforms 3 weeks after birth $[49,54,55]$.

\section{Vitamin A and intramuscular adipose tissue hyperplasia and hypertrophy}

Marbling (also referred to intramuscular fat) is agglomerated white streaks and flecks across the muscle surface [56], which profoundly affects the juiciness, tenderness, and flavor of the beef $[57,58]$. The accumulation of marbling is dependent on an increase in intramuscular adipocyte development, which frequently is associated with an increase in monounsaturated fatty acids [59].

\section{Vitamin A supplementation and intramuscular adipose tissue development in cattle}

The relationship between vitamin A and marbling score was firstly observed in Japanese Black cattle; vitamin A restriction during the fattening period increased marbling development [6]. Subsequently, other studies addressing the effects of vitamin A status and marbling score were conducted in other breed types of cattle, such as Angus crossbred steers, Simmental steers, feedlot heifers [7, 8], and Korean native steers [9] (Table 1). Some studies indicated an increase in marbling with vitamin A restriction, but other studies reported no significant effects with vitamin A restriction. There was a fact ignored for many years that pro-vitamin A (carotenoids) in feedstuffs might contain a large amount of vitamin A equivalents which could limit the effect of vitamin A restriction. The extensive assessment of vitamin A content in the feedstuff need to be conducted for a better vitamin A restriction in the beef cattle [65]. It appears that a very low level or no vitamin A supplementation (compared to National Research Council (NRC) requirements for beef cattle), including low or no supplementation before vitamin A treatments, were necessary during the vitamin A restriction period to elevate marbling scores and/or intramuscular fat (IMF) during the fattening period $[9,60,65-67]$.

A review of the nutrigenomic regulation of adipose tissue hypothesized that marbling development was initiated during the prenatal stage (late pregnancy) and postnatal stage (until about 250 days), which was associated with preadipocyte hyperplasia [68]. Oral administration of vitamin A $(78,000 \mathrm{IU} / \mathrm{d})$ during late-stage pregnancy increased birth weight of calves and increased the mRNA expression related to muscle [myogenic factor 5 (Myf5), myogenic factor 6 (Myf6), myoblast determination protein $1(M y o D)]$ and preadipocyte (Krüppel like factor 2 (KLF2)] development [69]. Vitamin A injection at birth and one-month age in Angus calves resulted in elevated intramuscular adipose tissue deposition in the carcass trait result when averagely slaughtered at day $438[14,70]$. Our previous study also 
Table 1 Studies reporting vitamin A restriction and marbling or intramuscular fat (IMF) in cattle

\begin{tabular}{|c|c|c|c|}
\hline $\begin{array}{l}\text { Breed } \\
\text { type }\end{array}$ & Treatment & General results/conclusions & Reference \\
\hline $\begin{array}{l}\text { Japanese } \\
\text { Black } \\
\text { steers }\end{array}$ & $\begin{array}{l}\text { Backgrounded at about } 20,000 \text { IU vitamin A/day, low vitamin } \\
\text { A (no extra supplementation) diet was fed from } 15 \text { to } 23 \\
\text { months of age }\end{array}$ & $\begin{array}{l}\text { Maintaining a low level of serum vitamin } \mathrm{A}(\leq 20 \mu \mathrm{g} / \mathrm{dL}) \\
\text { before } 23 \text { months of age may contribute to higher marbling } \\
\text { scores }\end{array}$ & {$[6]$} \\
\hline $\begin{array}{l}\text { Black } \\
\text { yearling } \\
\text { steers }\end{array}$ & $\begin{array}{l}\text { Backgrounded at } 1364 \text { IU vitamin A/kg DM, then } 0,1103,2205 \text {, } \\
4410 \text {, or } 8820 \text { IU supplemental vitamin/kg DM was fed for } 142 \\
\text { or } 143 \text { days }\end{array}$ & $\begin{array}{l}\text { Little effect was observed for performance, marbling, or } \\
\text { lipogenic enzyme activity in adipose tissue }\end{array}$ & [8] \\
\hline $\begin{array}{l}\text { Korean } \\
\text { native } \\
\text { steers }\end{array}$ & $\begin{array}{l}\text { Backgrounded at } 8890 \mathrm{IU} \text { vitamin A/kg DM, then } 8890 \text { (Con), } \\
3890 \text { (T1), or } 890 \text { (T2) IU restricted vitamin A/kg DM was fed } \\
\text { for } 240 \text { days }\end{array}$ & $\begin{array}{l}\text { Marbling scores in the vitamin A-restricted groups were not } \\
\text { significantly higher than in the control group but showed a } \\
\text { trend for a higher yield grade }\end{array}$ & [9] \\
\hline $\begin{array}{l}\text { Feedlot } \\
\text { heifers }\end{array}$ & $\begin{array}{l}\text { Backgrounded at } 3640 \text { IU vitamin A/kg DM, then } 3640 \text { or } 0 \text { IU } \\
\text { vitamin A/kg DM was fed for } 218 \text { days }\end{array}$ & $\begin{array}{l}\text { Vitamin A restriction increased the degree of marbling } \\
\text { without affecting backfat thickness }\end{array}$ & [60] \\
\hline $\begin{array}{l}\text { Holstein } \\
\text { steers }\end{array}$ & $\begin{array}{l}\text { Backgrounded at } 2700 \text { IU vitamin A/kg DM, then } 2200 \text { or } 950 \\
\text { IU of vitamin A/kg DM was fed for } 112 \text { days or } 243 \text { days ( } 2200 \\
\text { IU for } 112 \text { days and } 950 \text { IU for latter } 131 \text { days) }\end{array}$ & $\begin{array}{l}\text { Feeding the restricted vitamin A } 243 \text { days increased IMF } \\
\text { without affecting subcutaneous or visceral fat deposition }\end{array}$ & [61] \\
\hline $\begin{array}{l}\text { Feedlot } \\
\text { heifers }\end{array}$ & $\begin{array}{l}\text { Backgrounded at }<1300 \mathrm{IU} \text { vitamin A/kg DM, then } 0 \text { or } 2700 \\
\text { IU supplemental vitamin A/kg DM was fed for } 168 \text { days }\end{array}$ & $\begin{array}{l}\text { The percentage of carcasses grading } \geq \text { Choice }^{-} \text {was not } \\
\text { different between treatment groups }\end{array}$ & [62] \\
\hline $\begin{array}{l}\text { Feedlot } \\
\text { heifers }\end{array}$ & $\begin{array}{l}\text { Backgrounded at }<1100 \mathrm{IU} \text { vitamin } \mathrm{A} / \mathrm{kg} \mathrm{DM} \text {, then } 0 \text { or } 2700 \\
\text { IU supplemental vitamin A/kg DM was fed for } 112 \text { or } 227 \text { days }\end{array}$ & $\begin{array}{l}\text { Vitamin A restriction did not affect USDA yield grade or } \\
\text { marbling score }\end{array}$ & [63] \\
\hline $\begin{array}{l}\text { Angus } \\
\text { steers }\end{array}$ & $\begin{array}{l}\text { Backgrounded at a low } \beta \text {-carotene and vitamin A cereal-based } \\
\text { ration (no detailed data), then } 0 \text { or } 60,000 \text { IU supplemental } \\
\text { vitamin A/100 kg of BW/day was fed for } 308 \text { days }\end{array}$ & $\begin{array}{l}\text { There was greater IMF in longissimus thoracis et lumborum } \\
\text { and greater seam fat, but there ws no significant change in } \\
\text { marbling score }\end{array}$ & [64] \\
\hline
\end{tabular}

reported that oral vitamin A supplementation also enhanced the growth performance of the neonatal Korean native calves, as well as promoted the preadipocyte [zinc finger protein 423 (Zfp423), preadipocyte factor 1 (Pref1)] and muscle (MyoD, Myf6, myogenin) development in the genetic level [71]. Besides, vitamin A intake in the early growth stage in rats led to greater adiposity in rats [70]. These results implied that vitamin A supplementation in the late pregnancy and neonatal calves enhances the preadipocyte development, which further indirectly promotes the intramuscular adipose tissue deposition in the late stage of cattle. Therefore, these studies indicate that during early developmental stage, vitamin A supplementation promotes the adipogenic progenitor cells by preadipocyte hyperplasia process. However, in the fattening stage, vitamin A supplementation stimulates the lipid oxidation, thus restriction of vitamin A increases the lipid accumulation by the adipocyte hypertrophy.

\section{Vitamin A, preadipocyte hyperplasia, and adipocyte hypertrophy}

There have been several investigations of the effects of vitamin $\mathrm{A}$ on adipogenesis and subsequent development of intramuscular adipose tissue, which are summarized in Fig. 1. During the adipogenic differentiation period (adipocyte hypertrophy), the effects of retinoic acid are regulated by the $R A R$ and $R X R$ families in the promoter region of target genes [72, 73]. In particular, all-transretinoic acid supplementation inhibited the expression of adipogenic marker genes, such as fatty acid binding protein 4 (FABP4), peroxisome proliferator-activated receptor gamma (PPAR ), and CCAAT/enhancer-binding protein alpha $(C / E B P \alpha)$ during the early differentiation stage [74]. The retinoic acid inhibits lipid accumulation by stimulating PPAR $\alpha / \beta / \delta$ in mature adipocytes which relates to lipid oxidation and catabolism [68]. As well as activating the Wnt/ $\beta$-catenin signaling pathway [Wnt family member 1 (Wnt-1), Wnt family member 4 (Wnt4), Wnt family member 10 (Wnt10b), and $\beta$-catenin] in 3T3-L1 cells, which may associate with the adipogenesis suppression induced by retinoic acid [11]. Supplementation of 9-cis retinoic acid inhibits adipogenesis by decreasing the PPARY and RXR levels in 3 T3-L1 cells [74] and induced liver $F A B P$ gene expression above the induction caused by oleic acid in the subconfluent rat hepatoma cells [75]. In addition, all-trans retinoic acid supplementation activated $R A R$ and peroxisome proliferator-activated receptor beta/delta $(P P A R \beta / \delta)$ in mature adipocytes [76], stimulated transforming growth factor $\beta$-effector protein (mothers against decapentaplegic homolog 3, Smad3), blocked the phosphorylation of CCAAT/enhancer-binding protein beta (C/EBP $\beta)$, thereby decreasing the adipogenesis [77, 78]. Vitamin A reduced cellular triacylglycerol content and upregulated the fatty acid oxidation rate by increasing the expression of UCP gene family $[10,79]$. Also, demethylation in the promotor of $Z f p 423$ was disrupted by retinoic acid [80]. Interestingly, a recent study demonstrated that retinoic acid supplementation regulates adipogenesis and cell proliferation through both positive and negative 


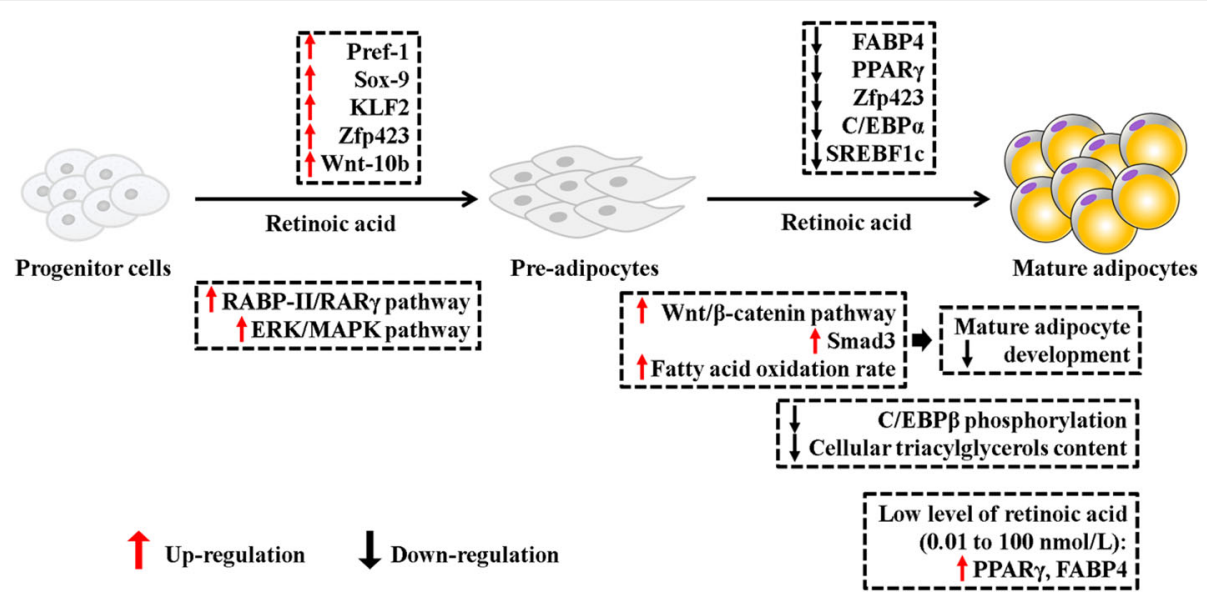

Fig. 1 Retinoic acid supplementation plays various roles that vary from preadipocyte development to the adipocyte deposition. The full names of genes are preadipocyte factor-1 (Pref-1), Krüppel-like factor 2 (KLF2), zinc finger protein 423 (Zfp423), Wnt family member 10b (Wnt-10b), fatty acid binding protein 4 (FABP4), peroxisome proliferator-activated receptor gamma (PPARY), CCAAT/enhancer-binding protein alpha/beta (C/EBPa/ $\beta$ ), sterol regulatory element binding protein 1c (SREBF1c), extracellular signal-regulated kinase 1/2 (ERK), mitogen-activated protein kinase (MAPK), retinoic acid binding protein (RABP), retinoic acid receptor gamma (RARY)

functions, which depended on retinoic acid dosage during the differentiation period [81]; fatty acid oxidation only occurred at specific concentrations.

More attention has been paid to the influence of retinoic acid on preadipocyte hyperplasia in recent years. Previous studies demonstrated that Pref-1, Sox-9, Wnt-10b, Zfp 423 , and KLF2 were expressed at high levels in preadipocytes but not in mature adipocytes [82-84]. Retinoic acid inhibited adipocyte differentiation by activation of the cellular retinoic acid-binding protein $2 /$ retinoic acid receptor (CRABP-II/RAR) pathway, but decreased the expression of Pref-1, Sox-9, and KLF2 in mature adipocytes, which typically are highly expressed only in preadipocytes [13]. Also, the activation of the ERK/ $M A P K$ pathway was required during the adipogenic commitment process by retinoic acid treatment in embryonic stem cells [85]. These results were summarized in Fig. 1, which shows that retinoic acid plays a crucial role in the development of the preadipocyte hyperplasia by activating related genes and stimulating the progenitor proliferation by the signaling pathway. When come to the adipogenic differentiation period, retinoic acid shows the inhibition of lipid accumulation and down-regulated the related genes expression. Paradoxically, low levels of vitamin A supplementation also promotes adipogenesis.

\section{Vitamin A, myoblast hyperplasia, and myotube differentiation}

Taylor and Jones [86] demonstrated that myoblasts and adipocytes can be derived from the same mesodermal stem cell precursors, which is dependent on upregulation of Wnt signalling [87]. Mesodermal stem cell precursors are activated by paired box (Pax) 3 and 7 during somitogenesis [88]. The muscle lineage is determined by the muscle-specific transcription $M y o D$ and $M y f 5$ at an early stage of embryonic development [89]. Followed by proliferation, a pool of myoblasts is formed following the expression of $M y f 5$ and $M y o D$ genes in the initial stage of muscle differentiation [90]. Following terminal differentiation, multinucleated myotubes are established by the expression of muscle-specific genes such as Myf6, myogenin, and myocyte enhancer factor 2 (MEF2) genes [91]. Subsequently, myotubes form myofibers following extensive myobril synthesis [92, 93].

Metabolites of retinoic acid can promote myogenic differentiation [88, 94]. In zebrafish, the retinoic acid activates muscle differentiation in vivo through fibroblast growth factor 8 (Fgf8) gene signaling, a muscle differentiation activator; suppression of retinoic acid signaling inhibits muscle differentiation and myoD expression [95]. The ovine primary myoblasts, retinoic acid dramatically decreased cell proliferation by a reduction of cyclin D1 protein, but retinoic acid increased myogenin gene expression and $\mathrm{MyHC}$ protein levels, and upregulated the glucose transporter 4 (GLUT4) mRNA and protein expression [96]. Retinoic acid treatment of human embryonic stem cells expanded the premyogenic progenitor population, promoting the Pax3positive myoblast population and elevating the expression of $M y o D$, myogenin, and mesenchyme homeobox 1 (Meox1) [97]. In addition, a high dose level of retinoic acid supplementation in the $\mathrm{C} 2 \mathrm{C} 12$ cell line still stimulated the myogenic differentiation, but the MyHC protein level was obviously decreased [98]. 
All-trans-retinoic acid promoted myogenin expression but had no effect on the cell cycle arrest in the rhabdomyosarcoma cell line [99, 100]. Maternal vitamin A deficiency in rats did not affect fetal weight but decreased survival rate as well as downregulated the protein level of Myf5, myogenin, and $\mathrm{MyHC}$ expression compared to rats receiving moderate vitamin A supplementation [101]. In addition, previous study in Black Angus steer calves reported that vitamin A injection to the neonatal calves upregulated the expression of myogenic genes (Pax3, Pax7, Myf5, MyoD and myogenin) [15]. Besides, our previous study also showed that oral vitamin A supplementation to the Korean native calves enhanced the expression of MyoD, Myf6 and myogenin in the longissimus dorsi muscle as well as the growth performance [71].

In Fig. 2, we conclude that retinoic acid plays an essential role myogenic commitment from the progenitor cells, the deficiency of retinoic acid may decrease the later myogenesis in the genetic levels. In terminal myogenesis, low levels of vitamin A promotes the formation of the myotubes as well as the related gene expression, however high levels of supplementation may have the side effect on maturation of myotubes by influencing the MyHC protein level.

\section{Vitamin A and metabolites in cattle}

Besides, with the deepening research of marbling in cattle, various potential biochemical parameters have been found related to the marbling score under vitamin A treatment. Adachi et al. [102] reported that with in the case of vitamin A restriction, the high serum concentration of glucose, urea nitrogen, albumin/globulin ratio and magnesium showed in the high marbling group than that in control group. Another monitor research in cattle by our lab revealed that, vitamin A restriction led the increase of the level of calcium, total cholesterol, albumin, blood urea nitrogen, creatinine and non-esterified fatty acids in serum $[9,103]$. These discovered metabolic indicators may contribute to the marbling production in cattle as well as the metabolic imbalances during the vitamin A restriction. Recently, the other latest research in our lab indicated that vitamin A supplementation in the early growth period of calf increased the levels of cholesterol and myo-inositol both in serum and longissimus dorsi muscle to maintain the preadipocyte status [104].

\section{Vitamin A, marbling, and the ADH1C genotype in cattle}

As stated above, retinol is oxidized into retinaldehyde by $\mathrm{RDH}$ and $\mathrm{ADH}$, and retinaldehyde is further oxidized into retinoic acid by RALDH and ALDH [17]. Serum retinaldehyde concentration was dramatically lower in

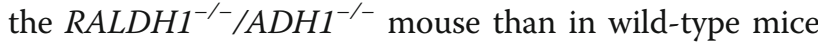
[105]. An ADH1C SNP was reported in Angus steers, including TT, TC, and CC genotypes. The TT genotype was more common than the CC genotype, with the TC genotype intermediate [106, 107]. The result suggested that the lower performance of the $\mathrm{C}$ allele might reduce the transcription of the $A D H 1 C$ gene by elimating a potential binding site of $C / E B P \alpha$ [108]. Under vitamin A restriction, the TT genotype of $A D H 1 C$ resulted in a higher level of intramuscular fat than the $\mathrm{CC}$ and $\mathrm{CT}$ genotypes [106]. A subsequent study in Angus steers reported that $75 \%$ of NRC recommended vitamin A supplementation caused greater intramuscular fat for Angus crossbred steers with the $A D H 1 C$ TT genotype of

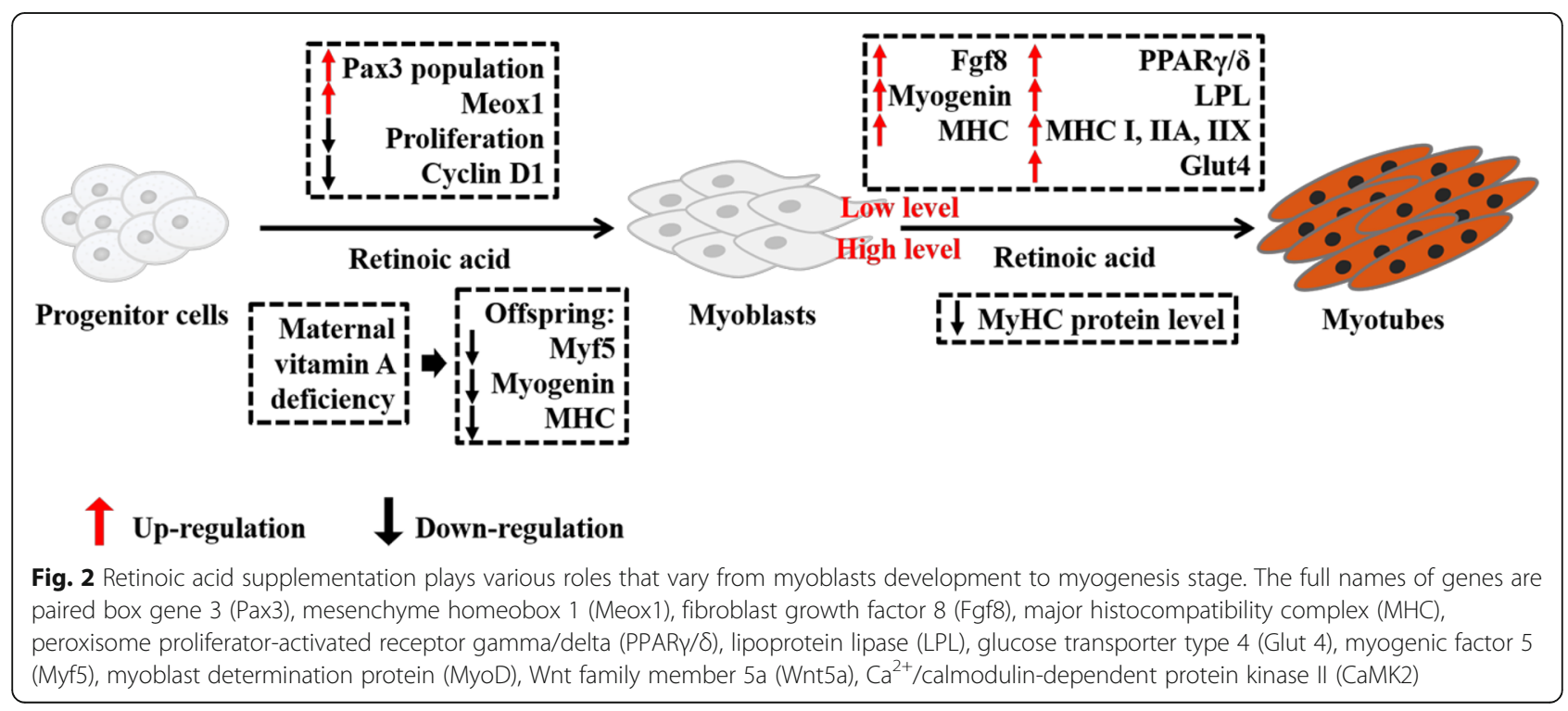


$A D H 1 C$ gene than steers with the CT or CC genotype [106]. However, vitamin A restriction at $25 \%$ or $50 \%$ of NRC recommendations had no effect on final levels of intramuscular fat [107].

All-trans-retinoic acid increases the expression of $P P A R \gamma / \delta, L P L, S M A D 3$, and MyHCIIX in cultured bovine satellite cells at relatively high doses, and increases MyHCI and MyHCIIA expression at low levels via the PPAR $\delta$ pathway [16]. High marbling scores in Korean native cattle (Hanwoo) are associated with a greater percentage of type I muscle fibers and fewer type IIB muscle fibers [109], which may be related to the level of retinoic acid supplementation during production. In a study in Korean native steers, steers with the $A D H 1 C$ TC genotype had higher marbling score than the TT genotype under vitamin A restriction (930 IU/ $/ \mathrm{kg}$ of $\mathrm{DM})$; the $A D H 1 C \mathrm{CC}$ genotype was not detected in this group of Korean native cattle [110].

Table 2 summarizes the results from the only four published reports of the interaction between ADH1C phenotype and vitamin A supplementation. Three studies [106, 107, 110] observed an increase in marbling with vitamin A restriction, but the $A D H 1 C$ genotype that was affected by vitamin A restriction (TT or TC) differed among these studies. One large study from Canada [111] demonstrated no effect of vitamin A restriction (to $50 \%$ recommended levels); nor did observe a vitamin $\mathrm{A} \times A D H 1 C$ (TT, TC, and $\mathrm{CC}$ genotypes) interaction for marbling. Breed types, basal diets, and countries in which the experiments were conducted may have led to the differing results. Moreover, these inconsistencies probably caused by the different effects of retinoic acid in preadipocyte hyperplasia and hypertrophy among these different vitamin A treated levels and different experimental periods. In spite of the inconsistent results among studies, subsequent experiments are warranted to study the interesting interaction between $A D H 1 C$ genotypes and dietary vitamin A levels.

\section{Limitations and conclusion}

According to the previous studies, vitamin A feeding strategy played a crucial role on the development of marbling or intramuscular fat in cattle. Several in vivo studies documented that vitamin A restriction of cattle during the fattening period increased intramuscular fat in carcasses (by adipocyte hypertrophy), but the broad applicability of vitamin A restriction in beef cattle production is equivocal and warrants further investigation. Current study suggested that vitamin A restriction did not affect backfat depth or lean mass. Furthermore, the effect of vitamin A on preadipocyte hyperplasia was reported in limited studies in beef cattle, however, the inside mechanism by in vivo or in vitro trials remains to be determined. In addition, existing data suggests that vitamin A contributes to myogenic commitment from progenitor cells and myogenesis in a narrow level of vitamin A supplementation. Although some studies in mouse and fish demonstrated that vitamin A would increase muscle development, few experiments have shown that vitamin A is efficacious for promoting muscle growth in cattle. These findings suggest that vitamin A supplementation during the early stage enhances the preadipocyte hyperplasia, but the restriction of vitamin A during the fattening period increases the lipid accumulation by adipocyte hypertrophy. A limited number of studies demonstrated that $A D H 1 C$ genotype (TT and $\mathrm{TC}$, depending on breed type) contributes to marbling production under vitamin A restriction, and again results are equivocal. Larger studies comparing the effects of vitamin A restriction between different breed types (e.g., Korean native cattle and Holstein or Angus cattle) should be encouraged.

Table 2 Studies reporting vitamin A restriction and the ADH1C genotype in cattle

\begin{tabular}{|c|c|c|c|}
\hline $\begin{array}{l}\text { Experimental } \\
\text { details }\end{array}$ & Treatments & Effects on marbling or intramuscular fat (IMF) & Reference \\
\hline $\begin{array}{l}\text { Angus-cross steers } \\
(n=130 ; 50 \mathrm{TT}, 50 \mathrm{TC}, \\
30 \mathrm{CC})\end{array}$ & $\begin{array}{l}\text { Backgrounded at } 549 \mathrm{IU} \text { vitamin } \mathrm{A} / \mathrm{kg} \text { DM } \\
\text { then fed } 0 \text { or } 2200 \text { supplemental IU vitamin } \\
\text { A/kg DM }\end{array}$ & $\begin{array}{l}\text { Un-supplemented steers had greater marbling scores and IMF than } \\
\text { supplemented steers. There was a significant treatment } \times \\
\text { genotype interaction for IMF. With no vitamin A supplementation, } \\
\text { TT steers had } 23 \% \text { greater IMF than CC steers. Un-supplemented TT } \\
\text { steers had } 24 \% \text { greater IMF than supplemented TT steers }\end{array}$ & {$[106]$} \\
\hline $\begin{array}{l}\text { Angus-cross steers } \\
(n=117 ; 45 \mathrm{TT}, 45 \mathrm{TC}, \\
27 \mathrm{CC})\end{array}$ & $\begin{array}{l}\text { Backgrounded at } 3360 \text { IU vitamin } \mathrm{A} / \mathrm{kg} \mathrm{DM} \text {, } \\
\text { then fed 550, 1100, or } 1650 \text { total IU vitamin } \\
\text { A/kg DM }\end{array}$ & $\begin{array}{l}\text { A treatment } \times \text { genotype interaction was observed for IMF; } \Pi T \\
\text { steers on the } 1650 \mathrm{IU} / \mathrm{kg} \text { DM treatment had higher IMF relative to } \\
\mathrm{CT} \text { and } \mathrm{CC} \text { steers on the same treatment }\end{array}$ & {$[107]$} \\
\hline $\begin{array}{l}\text { Korean native steers } \\
(n=136 ; 102 \pi, 34 \\
\text { TC) }\end{array}$ & $\begin{array}{l}\text { Backgrounded at } 890 \mathrm{IU} \text { vitamin A/kg DM, } \\
\text { then fed } 930 \mathrm{IU} \text { total vitamin A/kg DM }\end{array}$ & $\begin{array}{l}\text { Marbling scores were greater for the TC genotype than the TT } \\
\text { genotype following a vitamin A-restricted diet }\end{array}$ & {$[110]$} \\
\hline $\begin{array}{l}\text { Black Angus steers } \\
(n=2000 ; T \text { and TC), } \\
\text { mixed breed }\end{array}$ & $\begin{array}{l}\text { Backgrounded on } 3360 \text { IU vitamin A/kg DM, } \\
\text { then fed } 1100 \text { or } 2200 \text { IU total vitamin A/kg } \\
\text { DM }\end{array}$ & $\begin{array}{l}\text { There was not a significant vitamin } \mathrm{A} \times \mathrm{ADH} 1 \mathrm{C} \text { interaction for } \\
\text { marbling score }\end{array}$ & {$[111]$} \\
\hline
\end{tabular}




\section{Abbreviations}

ADH1C: Alcohol dehydrogenase-1C; RDH: Retinol dehydrogenase; ADH: Alcohol dehydrogenase; RALDH: Retinaldehyde; ALDH: Aldehyde dehydrogenases; RAR: Retinoic acid receptor; RARY: Retinoic acid receptor gamma; RXR: Retinoid X receptor; CRABP: Cellular retinoic acid-binding proteins (1 and 2); BAT: Brown adipose tissue; UCP1: Uncoupling protein-1; WAT: White adipose tissue; MyHC: Myosin heavy chain; NRC: National Research Council; IMF: Intramuscular fat; Myf5/6: Myogenic factor 5/6; MyoD: Myoblast determination protein 1; KLF2: Krüppel-like factor 2; Zfp423: Zinc finger protein 423; Pref-1: Preadipocyte factor-1; FABP4: Fatty acid binding protein 4; PPARa/ $/ / \gamma / \delta$ : Peroxisome proliferator-activated receptor alpha/beta/gamma/delta; C/EBPa/ 3 : CCAAT/enhancer-binding protein alpha/beta; Wnt-1/4/10b: Wnt family member 1/4/10b; Smad3: Mothers against decapentaplegic homolog 3; SREBF1c: Sterol regulatory element binding protein 1c; ERK 1/2: Extracellular signal-regulated kinase 1/2; MAPK: Mitogen-activated protein kinase; RABP: Retinoic acid binding protein; Pax3/7: Paired box gene 3/7; Meox1: Mesenchyme homeobox 1; Fgf8: Fibroblast growth factor 8; MHC: Major histocompatibility complex; LPL: Lipoprotein lipase; GLUT4: Glucose transporter type 4; MEF2: Myocyte enhancer factor 2

\section{Authors' contributions}

HGL and DQP designed this review. DQP wrote the manuscript. HGL and DQP revised the manuscript. SBS revised the manuscript for content and English grammar and usage. All authors read and approved the final manuscript.

\section{Funding}

This work was supported by a Cooperation Research Project (2020R1A2B5B02001843) funded by the National Research Foundation of Korea.

\section{Availability of data and materials}

Not applicable.

\section{Ethics approval and consent to participate}

Not applicable.

\section{Consent for publication}

Not applicable.

\section{Competing interests}

The authors declare no conflicts of interest.

\section{Author details}

'Department of Animal Science and Technology, Sanghuh College of Life Sciences, Konkuk University, Seoul 05029, South Korea. ${ }^{2}$ Department of Animal Science, Texas A\&M University, College Station, TX 77843, USA.

Received: 7 September 2020 Accepted: 18 January 2021 Published online: 05 March 2021

\section{References}

1. Jo C, Cho SH, Chang J, Nam KC. Keys to production and processing of Hanwoo beef: a perspective of tradition and science. Animal Frontiers. 2012; 2:32-8.

2. Gotoh T, Takahashi H, Nishimura T, Kuchida K, Mannen H. Meat produced by Japanese black cattle and Wagyu. Animal Frontiers. 2014:4:46-54

3. USDA. United States Standards for Grades of Carcass Beef. Agricultural Marketing Service, USDA, 2017. https://www.ams.usda.gov/sites/default/files/ media/CarcassBeefStandard.pdf. Accessed 21 Jan 2021.

4. Han S, Kondo N, Fujiura T, Ogawa Y, Takao Y, Tanigawa S, et al. Machine vision based prediction of serum vitamin A level in Japanese black cattle by pupillary light reflex analysis. In: IEEE/SICE international symposium on system integration (SII), vol. 2011: IEEE; 2011. p. 178-81.

5. NRC. Nutrient requirements of beef cattle. 8th ed. Washington, DC: National Academies Press; 2016.

6. Oka A, Maruo Y, Miki T, Yamasaki T, Saito T. Influence of vitamin A on the quality of beef from the Tajima strain of Japanese black cattle. Meat Sci. 1998;48:159-67.
7. Gorocica-Buenfil MA, Fluharty FL, Bohn T, Schwartz SJ, Loerch SC. Effect of low vitamin A diets with high-moisture or dry corn on marbling and adipose tissue fatty acid composition of beef steers. J Anim Sci. 2007;85: 3355-66.

8. Bryant TC, Wagner JJ, Tatum JD, Galyean ML, Anthony RV, Engle TE. Effect of dietary supplemental vitamin A concentration on performance, carcass merit, serum metabolites, and lipogenic enzyme activity in yearling beef steers. J Anim Sci. 2010;88:1463-78.

9. Peng D-Q, Lee J-S, Kim W-S, Kim Y-S, Bae M-H, Jo Y-H, et al. Effect of vitamin $A$ restriction on carcass traits and blood metabolites in Korean native steers. Anim Prod Sci. 2019:59:2138-46.

10. Mercader J, Madsen L, Felipe F, Palou A, Kristiansen K, Bonet L. All-trans retinoic acid increases oxidative metabolism in mature adipocytes. Cell Physiol Biochem. 2007;20:1061-72.

11. Kim DM, Choi HR, Park A, Shin SM, Bae KH, Lee SC, et al. Retinoic acid inhibits adipogenesis via activation of Wnt signaling pathway in 3T3-L1 preadipocytes. Biochem Biophys Res Commun. 2013;434:455-9.

12. Smith SB, Kawachi $H$, Choi CB, Choi CW, Wu G, Sawyer JE. Cellular regulation of bovine intramuscular adipose tissue development and composition. J Anim Sci. 2009;87:E72-82.

13. Berry DC, DeSantis D, Soltanian H, Croniger CM, Noy N. Retinoic acid upregulates preadipocyte genes to block adipogenesis and suppress dietinduced obesity. Diabetes. 2012;61:1112-21.

14. Harris CL, Wang B, Deavila JM, Busboom JR, Maquivar M, Parish SM, et al. Vitamin A administration at birth promotes calf growth and intramuscular fat development in Angus beef cattle. J Anim Science Biotechnol. 2018;9:55.

15. Wang B, Nie W, Fu X, de Avila JM, Ma Y, Zhu MJ, et al. Neonatal vitamin A injection promotes cattle muscle growth and increases oxidative muscle fibers. J Anim Sci Biotechnol. 2018:9:82

16. Kim J, Wellmann KB, Smith ZK, Johnson BJ. All-trans retinoic acid increases the expression of oxidative myosin heavy chain through the PPAR $\delta$ pathway in bovine muscle cells derived from satellite cells. J Anim Sci. 2018; 96:2763-76.

17. Chen $\mathrm{W}, \mathrm{Chen} \mathrm{G}$. The roles of vitamin $\mathrm{A}$ in the regulation of carbohydrate, lipid, and protein metabolism. J Clin Med. 2014;3:453-79.

18. Church DC, Pond WG. Basic animal nutrition and feeding. 3rd ed. New York: Wiley; 1988.

19. Borel P, Drai J, Faure H, Fayol V, Galabert C, Laromiguiere M, et al. Recent knowledge about intestinal absorption and cleavage of carotenoids. Ann Biol Clin (Paris). 2005;63(2):165-77.

20. Goodman DS, Huang HS. Biosynthesis of vitamin A with rat intestinal enzymes. Science. 1965;149:879-80.

21. Rigtrup KM, Ong DE. A retinyl ester hydrolase activity intrinsic to the brush border membrane of rat small intestine. Biochemistry. 1992;31:2920-6.

22. Harrison EH. Mechanisms of digestion and absorption of dietary vitamin A. Annu Rev Nutr. 2005:25:87-103.

23. Napoli JL. Physiological insights into all-trans-retinoic acid biosynthesis. Biochim Biophys Acta. 2012;1821:152-67.

24. Chen $\mathrm{G}$. Roles of vitamin A metabolism in the development of hepatic insulin resistance. ISRN Hepatol. 2013:2013:534972.

25. Wolf $\mathrm{G}$. Tissue-specific increases in endogenous all-trans retinoic acid: possible contributing factor in ethanol toxicity. Nutr Rev. 2010;68:689-92.

26. Blomhoff R, Blomhoff HK. Overview of retinoid metabolism and function. J Neurobiol. 2006:66:606-30.

27. Frey SK, Vogel S. Vitamin A metabolism and adipose tissue biology. Nutrients. 2011:3:27-39.

28. Napoli JL. Functions of intracellular retinoid binding-proteins. Subcell Biochem. 2016;81:21-76.

29. Napoli JL. Cellular retinoid binding-proteins, CRBP, CRABP, FABP5: effects on retinoid metabolism, function and related diseases. Pharmacol Ther. 2017; 173:19-33.

30. Berry DC, Soltanian H, Noy N. Repression of cellular retinoic acid-binding protein II during adipocyte differentiation. J Biol Chem. 2010;285:15324-32.

31. Blomhoff $R$, Rasmussen M, Nilsson A, Norum KR, Berg T, Blaner WS, et al. Hepatic retinol metabolism. Distribution of retinoids, enzymes, and binding proteins in isolated rat liver cells. J Biol Chem. 1985;260:13560-5.

32. Palace VP, Khaper N, Qin Q, Singal PK. Antioxidant potentials of vitamin A and carotenoids and their relevance to heart disease. Free Radic Biol Med. 1999;26:746-61. 
33. Tesoriere L, Ciaccio M, Bongiorno A, Riccio A, Pintaudi AM, Livrea MA. Antioxidant activity of all-trans-retinol in homogeneous solution and in phosphatidylcholine liposomes. Arch Biochem Biophys. 1993;307:217-23.

34. Ross AC, Gardner EM. The function of vitamin A in cellular growth and differentiation, and its roles during pregnancy and lactation. Adv Exp Med Biol. 1994;352:187-200.

35. Lewis AJ, Southern LL. Swine nutrition. 2nd ed. Boca Raton: CRC Press; 2001.

36. Smith S, Carstens G. Ontogeny and metabolism of brown adipose tissue in livestock species. In: Burrin DG, Mersmann HJ, editors. Biology of Metabolism in Growing Animals. 2005;3:303. https://doi.org/10.1016/S18771823(09)70019-0.

37. Landis MD, Carstens GE, McPhail EG, Randel RD, Green KK, Slay L, et al. Ontogenic development of brown adipose tissue in Angus and Brahman fetal calves. J Anim Sci. 2002;80:591-601.

38. Large V, Peroni O, Letexier D, Ray H, Beylot M. Metabolism of lipids in human white adipocyte. Diabetes Metab. 2004;30:294-309.

39. Himms-Hagen J. Brown adipose tissue thermogenesis: interdisciplinary studies. FASEB J. 1990;4:2890-8

40. Symonds ME, Pope M, Sharkey D, Budge H. Adipose tissue and fetal programming. Diabetologia. 2012;55:1597-606.

41. Martin GS, Carstens GE, King MD, Eli AG, Mersmann HJ, Smith SB Metabolism and morphology of brown adipose tissue from Brahman and Angus newborn calves. J Anim Sci. 1999;77:388-99.

42. Jo J, Gavrilova O, Pack S, Jou W, Mullen S, Sumner AE, et al. Hypertrophy and/or hyperplasia: dynamics of adipose tissue growth. PLoS Comput Biol. 2009;5:e1000324.

43. Hocquette J, Gondret F, Baéza E, Médale F, Jurie C, Pethick D. Intramuscular fat content in meat-producing animals: development, genetic and nutritional control, and identification of putative markers. Animal. 2010;4: 303-19.

44. Du M, Tong J, Zhao J, Underwood KR, Zhu M, Ford SP, et al. Fetal programming of skeletal muscle development in ruminant animals. J Anim Sci. 2010;88:E51-60.

45. Allen C. Biology of Fat in Meat Animals. University of Wisconsin-Madison. 1976

46. Hausman G, Dodson M, Ajuwon K, Azain M, Barnes K, Guan L, et al. Boardinvited review: the biology and regulation of preadipocytes and adipocytes in meat animals. J Anim Sci. 2009:87:1218-46.

47. Brooks M, Choi C, Lunt D, Miller R, Choi C, Smith S. CASE STUDY: carcass and meat characteristics and $\mathrm{M}$. longissimus thoracis histology of beef from calf-fed and yearling-fed Angus steers. Prof Anim Sci. 2011;27:385-93.

48. May SG, Savell JW, Lunt DK, Wilson JJ, Laurenz JC, Smith SB. Evidence for preadipocyte proliferation during culture of subcutaneous and intramuscular adipose tissues from Angus and Wagyu crossbred steers. J Anim Sci. 1994;72:3110-7.

49. Bonnet M, Cassar-Malek I, Chilliard Y, Picard B. Ontogenesis of muscle and adipose tissues and their interactions in ruminants and other species. Animal. 2010;4:1093-109.

50. Brameld JM, Fahey AJ, Langley-Evans SC, Buttery PJ. Nutritional and hormonal control of muscle growth and fat deposition. Archiv Fur Tierzucht. 2003:46:143-56.

51. Greenwood PL, Slepetis RM, Bell AW. Influences on fetal and placental weights during mid to late gestation in prolific ewes well nourished throughout pregnancy. Reprod Fertil Dev. 2000;12:149-56.

52. Greenwood PL, Slepetis RM, Bell AW, Hermanson JW. Intrauterine growth retardation is associated with reduced cell cycle activity, but not myofibre number, in ovine fetal muscle. Reprod Fertil Dev. 1999;11:281-91.

53. Picard B, Robelin J, Pons F, Geay Y. Comparison of the foetal development of fibre types in four bovine muscles. J Muscle Res Cell Motility. 1994;15:473-86.

54. Picard B, Lefaucheur L, Berri C, Duclos MJ. Muscle fibre ontogenesis in farm animal species. Reprod Nutr Dev. 2002;42:415-31.

55. Picard B, Jurie C, Duris M, Renand G. Consequences of selection for higher growth rate on muscle fibre development in cattle. Livest Sci. 2006;102:107-20.

56. Pethick D, Harper G, Oddy VH. Growth, development and nutritional manipulation of marbling in cattle: a review. Aust J Exp Agric. 2004;44:705-15.

57. Shiranita K, Hayashi K, Otsubo A, Miyajima T, Takiyama R. Grading meat quality by image processing. Pattern Recogn. 2000;33:97-104.
58. Wood JD, Enser M, Fisher AV, Nute GR, Sheard PR, Richardson Rl, et al. Fat deposition, fatty acid composition and meat quality: a review. Meat Sci. 2008;78:343-58

59. Smith SB, Lunt DK. Marbling: management of cattle to maximize the deposition of intramuscular adipose tissue. In: Plains Nutrition Council Spring Conference, vol. 26; 2007.

60. Gibb D, Van Herk F, Mir P, Loerch S, McAllister T. Removal of supplemental vitamin A from barley-based diets improves marbling in feedlot heifers. Can J Anim Sci. 2011:91:669-74.

61. Gorocica-Buenfil MA, Fluharty FL, Reynolds CK, Loerch SC. Effect of dietary vitamin A restriction on marbling and conjugated linoleic acid content in Holstein steers. J Anim Sci. 2007;85:2243-55.

62. Gorocica-Buenfil MA, Fluharty FL, Reynolds CK, Loerch SC. Effect of dietary vitamin A concentration and roasted soybean inclusion on marbling, adipose cellularity, and fatty acid composition of beef. J Anim Sci. 2007:85: 2230-42.

63. Pickworth C, Loerch S, Fluharty F. Effects of timing and duration of dietary vitamin A reduction on carcass quality of finishing beef cattle. J Anim Sci. 2012;90:2677-91.

64. Kruk Z, Bottema C, Davis J, Siebert B, Harper G, Di J, et al. Effects of vitamin A on growth performance and carcass quality in steers. Livest Sci. 2008;119:12-21.

65. Pickworth CL, Loerch SC, Kopec RE, Schwartz SJ, Fluharty FL. Concentration of pro-vitamin A carotenoids in common beef cattle feedstuffs. J Anim Sci. 2012;90:1553-61.

66. Knutson E, Sun X, Fontoura A, Gaspers J, Liu J, Carlin K, et al. Effect of a low vitamin A diet on marbling and carcass characteristics of Angus cross and Simmental steers. In: Proceedings, Western Section, American Society of Animal Science; 2017. p. 96-100.

67. Oka A. Effects of vitamin A on beef quality and body weight of Japanese black steers. J Anim Genet. 1996;24:31-6.

68. Wang B, Yang Q, Harris CL, Nelson ML, Busboom JR, Zhu M-J, et al. Nutrigenomic regulation of adipose tissue development-role of retinoic acid: a review. Meat Sci. 2016;120:100-6.

69. Jo YH, Peng DQ, Kim WS, Kim SJ, Kim NY, Kim SH, et al. The effects of vitamin A supplementation during late-stage pregnancy on longissimus dorsi muscle tissue development, birth traits, and growth performance in postnatal Korean native calves. Asian-Australas J Anim Sci. 2020;33:742-52.

70. Granados N, Amengual J, Ribot J, Musinovic H, Ceresi E, von Lintig J, et al. Vitamin A supplementation in early life affects later response to an obesogenic diet in rats. Int J Obes. 2013;37:1169-76.

71. Peng DQ, Jo YH, Kim SJ, Kim NY, Nejad JG, Lee HG. Oral vitamin A supplementation during neonatal stage enhances growth, pre-adipocyte and muscle development in Korean native calves. Anim Feed Sci Technol. 2020:268:114609.

72. Chambon P. A decade of molecular biology of retinoic acid receptors. FASEB J. 1996:10:940-54

73. Lefebvre P, Martin PJ, Flajollet S, Dedieu S, Billaut X, Lefebvre B. Transcriptional activities of retinoic acid receptors. Vitam Horm. 2005:70: 199-264.

74. Sagara C, Takahashi K, Kagechika H, Takahashi N. Molecular mechanism of 9cis-retinoic acid inhibition of adipogenesis in 3T3-L1 cells. Biochem Biophys Res Commun. 2013:433:102-7.

75. Poirier H, Braissant O, Niot I, Wahli W, Besnard P. 9-cis-retinoic acid enhances fatty acid-induced expression of the liver fatty acid-binding protein gene. FEBS Lett. 1997;412:480-4.

76. Berry DC, Noy N. All-trans-retinoic acid represses obesity and insulin resistance by activating both peroxisome proliferation-activated receptor $\beta$ / $\delta$ and retinoic acid receptor. Mol Cell Biol. 2009;29:3286-96.

77. Ayala-Sumuano JT, Velez-DelValle C, Marsch-Moreno M, Beltran-Langarica A, Hernandez-Mosqueira C, Kuri-Harcuch W. Retinoic acid inhibits Adipogenesis modulating C/EBPbeta phosphorylation and down regulating Srebf1a expression. J Cell Biochem. 2016;117:629-37.

78. Marchildon F, St-Louis C, Akter R, Roodman V, Wiper-Bergeron NL. Transcription factor Smad3 is required for the inhibition of adipogenesis by retinoic acid. J Biol Chem. 2010;285:13274-84.

79. Bonet ML, Ribot J, Felipe F, Palou A. Vitamin A and the regulation of fat reserves. Cell Mol Life Sci. 2003:60:1311-21.

80. Wang B, Fu X, Zhu M-J, Du M. Retinoic acid inhibits white adipogenesis by disrupting GADD45A-mediated Zfp423 DNA demethylation. J Mol Cell Biol. 2017;9:338-49. 
81. Kim DH, Lee JW, Lee K. Supplementation of all-trans-retinoic acid below cytotoxic levels promotes Adipogenesis in 3T3-L1 cells. Lipids. 2019;54:99-107.

82. Zubiría M, Alzamendi A, Moreno G, Portales A, Castrogiovanni D, Spinedi E, et al. Relationship between the balance of hypertrophic/hyperplastic adipose tissue expansion and the metabolic profile in a high glucocorticoids model. Nutrients. 2016;8:410.

83. Sarjeant K, Stephens JM. Adipogenesis. Cold Spring Harb Perspect Biol. 2012;4:a008417.

84. Huang Y, Das AK, Yang QY, Zhu MJ, Du M. Zfp423 promotes adipogenic differentiation of bovine stromal vascular cells. PLoS One. 2012;7:e47496.

85. Bost F, Caron L, Marchetti I, Dani C, Le Marchand-Brustel Y, Binetruy B. Retinoic acid activation of the ERK pathway is required for embryonic stem cell commitment into the adipocyte lineage. Biochem J. 2002;361:621-7.

86. Taylor SM, Jones PA. Multiple new phenotypes induced in 10T12 and 3T3 cells treated with 5-azacytidine. Cell. 1979;17:771-9.

87. Cossu G, Borello U. Wnt signaling and the activation of myogenesis in mammals. EMBO J. 1999;18:6867-72.

88. Jin W, Peng J, Jiang S. The epigenetic regulation of embryonic myogenesis and adult muscle regeneration by histone methylation modification. Biochem Biophys Rep. 2016;6:209-19.

89. Imae M, Fu Z, Yoshida A, Noguchi T, Kato H. Nutritional and hormonal factors control the gene expression of FoxOs, the mammalian homologues of DAF-16. J Mol Endocrinol. 2003;30:253-62.

90. Buckingham M. Skeletal muscle formation in vertebrates. Curr Opin Genet Dev. 2001;11:440-8.

91. Johnston IA. Environment and plasticity of myogenesis in teleost fish. J Exp Biol. 2006;209:2249-64.

92. Pas MFW, Everts ME, Haagsman HP. Muscle development of livestock animals : physiology, genetics, and meat quality. Wallingford, Oxfordshire, UK. Cambridge, MA: CABI Pub; 2004.

93. Keren A, Tamir Y, Bengal E. The p38 MAPK signaling pathway: a major regulator of skeletal muscle development. Mol Cell Endocrinol. 2006;252: 224-30.

94. Le May M, Mach H, Lacroix N, Hou C, Chen J, Li Q. Contribution of retinoid $\mathrm{X}$ receptor signaling to the specification of skeletal muscle lineage. J Biol Chem. 2011;286:26806-12.

95. Hamade A, Deries M, Begemann G, Bally-Cuif L, Genet C, Sabatier F, et al. Retinoic acid activates myogenesis in vivo through Fgf8 signalling. Dev Biol. 2006;289:127-40.

96. Li Q, Zhang T, Zhang R, Qin X, Zhao J. All-trans retinoic acid regulates sheep primary myoblasts proliferation and differentiation in vitro. Domest Anim Endocrinol. 2019;106394.

97. Ryan T, Liu J, Chu A, Wang L, Blais A, Skerjanc IS. Retinoic acid enhances skeletal myogenesis in human embryonic stem cells by expanding the premyogenic progenitor population. Stem Cell Rev. 2012;8:482-93.

98. Liu B, Li N, Jiang Y, Liu C, Ma L, Cong W, et al. Effects of excessive retinoic acid on C2C12 myogenesis. J Hard Tissue Biol. 2016;25:97-103.

99. Al-Tahan A, Sarkis O, Harajly M, Baghdadi OK, Zibara K, Boulos F, et al. Retinoic acid fails to induce cell cycle arrest with myogenic differentiation in rhabdomyosarcoma. Pediatr Blood Cancer. 2012;58:877-84.

100. Arnold HH, Gerharz CD, Gabbert HE, Salminen A. Retinoic acid induces myogenin synthesis and myogenic differentiation in the rat rhabdomyosarcoma cell line BA-Han-1C. J Cell Biol. 1992;118:877-87.

101. Downie D, Antipatis C, Delday MI, Maltin CA, Sneddon AA. Moderate maternal vitamin A deficiency alters myogenic regulatory protein expression and perinatal organ growth in the rat. Am J Physiol Regul Integr Comp Physiol. 2005;288:R73-9.

102. Adachi K, Kawano H, Tsuno K, Nomura Y, Yamamoto N, Arikawa A, et al. Relationship between serum biochemical values and marbling scores in Japanese black steers. J Vet Med Sci. 1999;61:961-4.

103. Wang T, Lee KH, Jung US, Jin YC, Lee SB, Lee JS, et al. Responses of blood metabolites and proteins to different vitamin A levels in Korean native steers. Pak Vet J. 2014;34

104. Peng DQ, Kim SJ, Lee HG. Metabolomics analyses to characterize metabolic alterations in Korean native calves by oral vitamin A supplementation. Sci Rep. 2020;10:1-8.

105. Molotkov A, Duester G. Genetic evidence that retinaldehyde dehydrogenase Raldh1 (Aldh1a1) functions downstream of alcohol dehydrogenase Adh1 in metabolism of retinol to retinoic acid. J Biol Chem. 2003;278:36085-90.
106. Ward AK, McKinnon JJ, Hendrick S, Buchanan FC. The impact of vitamin A restriction and $\mathrm{ADH} 1 \mathrm{C}$ genotype on marbling in feedlot steers. J Anim Sci. 2012;90:2476-83.

107. Krone KG, Ward AK, Madder KM, Hendrick S, McKinnon JJ, Buchanan FC. Interaction of vitamin A supplementation level with ADH1C genotype on intramuscular fat in beef steers. Animal. 2016;10:403-9.

108. Chekmenev DS, Haid C, Kel AE. P-match: transcription factor binding site search by combining patterns and weight matrices. Nucleic Acids Res. 2005; 33:W432-7.

109. Hwang YH, Kim GD, Jeong JY, Hur SJ, Joo ST. The relationship between muscle fiber characteristics and meat quality traits of highly marbled Hanwoo (Korean native cattle) steers. Meat Sci. 2010;86:456-61.

110. Peng DQ, Jung US, Lee JS, Kim WS, Jo YH, Kim MJ, et al. Effect of alcohol dehydrogenase $1 \mathrm{C}(\mathrm{ADH} 1 \mathrm{C})$ genotype on vitamin A restriction and marbling in Korean native steers. Asian Australas J Anim Sci. 2017;30:1099.

111. Madder KM, McKinnon JJ, Torres GW, Krone KG, Duncombe JL, Luby CD, et al. Feedlot performance and immune function analysis of implanted and non-implanted steers selected for alcohol dehydrogenase $1 \mathrm{C}$ (ADH1C) genotype and fed a low vitamin A diet. Animal. 2019;13:292-300.

\section{Ready to submit your research? Choose BMC and benefit from:}

- fast, convenient online submission

- thorough peer review by experienced researchers in your field

- rapid publication on acceptance

- support for research data, including large and complex data types

- gold Open Access which fosters wider collaboration and increased citations

- maximum visibility for your research: over $100 \mathrm{M}$ website views per year

At $\mathrm{BMC}$, research is always in progress.

Learn more biomedcentral.com/submissions 